\title{
TAUNO AHON POLKANSOITTO SOUND DESIGNER -MAAILMASSA
}

Kuortanelainen kaksirivisen soittaja Tauno Aho syntyi Yhdysvalloissa Minnesotan osavaltiossa Hibbingin kaupungissa 10 päivänä heinäkuuta 1914 Kusti ja Hilja Ahon (os. Mustapää) poikana. Amerikassa Aho kuuli kaksirivisen soittoa jo pienenä poikana, koska hänen isällään oli kaksirivinen. Myös Kusti Ahon serkku "Kaarangan Jaakkoo" oli kaivosmiehenä samassa kaupungissa ja myös hän osasi soittaa kaksirivistä.

Vuonna 1924 Hilja Aho ja lapset muuttivat takaisin Suomeen ja siitä alkoi myös Tauno Ahon pelimanniura. Ensimmäiset häät hän soitti jo 13vuotiaana ja tietenkin salaa. 30-luvun alussa hän hankki monien muiden pelimannien tapaan itselleen viisirivisen ja töitä löytyikin soittajalle häissä, iltamissa, harjannostajaisissa ja sota-ajan viihdytyskiertueilla. Sodan jälkeen alkoi soittotilaisuuksia ilmaantua yhä enemmän. Siitä huolimatta leipää oli hankittava reissuhommissa Helsingissä, Tampereella, Vaasassa ja metsätyöt veivät mukanaan aina Ruotsiin saakka.

1950-luvulla kiinnostus kaksirivisen hanurin soittoa kohtaan heräsi Tauno Ahon mukaan uudestaan, kun kansansoittokilpailuja ryhdyttiin järjestämään Etelä-Pohjanmaalla. Ensimmäiset kilpailut, joihin Tauno Aho osallistui, järjestettiin Peräseinäjoella vuonna 1953. Tuloksena oli toinen palkinto. Siitä lähtien Aho olikin vakituinen osallistuja monissa kilpailuis- 
sa, myös hyvällä menestyksellä. Vuosi 1977 oli varsin merkittävä Tauno Aholle. Sinä vuonna hän ensin voitti Ikaalisissa Suomen Pelimannimestaruuden kaksirivisten hanureiden sarjassa ja myöhemmin kesällä hänet nimitettiin Kaustisten Kansanmusiikkijuhlilla Mestaripelimanniksi.

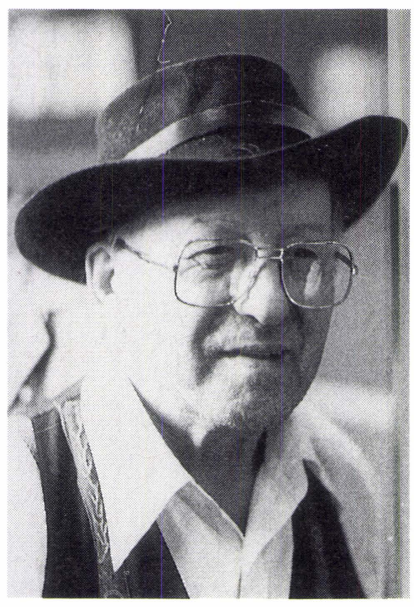

\section{Analyysistä}

Vaikka tietokonetta on jonkin verran käytetty kansanmusiikin tutkimuksessa, ei sitä tiettävästi ole koskaan käytetty kuvaamaan kaksirivisen harmonikan soittoa. Tässä tutkimuksessa käytössäni oli Apple Macintosh IIX tietokone ja analyysiohjelmana oli Digidesign-yhtiön julkaisema Sound Designer II ja Blank Software -yhtiön julkaisema Alchemy-ohjelma. Ohjelmat ovat alunperin suunniteltu M.I.D.I. standardin mukaisten laitteiden avuksi sävelten muokkaamiseen ja sovittamiseen sopivaksi esim. mainosmusiikkeihin. Sound Designer II ohjelma mittaa esimerkiksi signaalissa tapahtuvat intensiteetin muutokset ja Alchemy-ohjelmasta on mahdollista saada samat tiedot numeerisina.

Harmonikan soittoa kokonaisuutena olisi mahdotonta analysoida tietokoneella, koska harmonikansoitto muodostuu diskantin usein yksiäänisestä melodiasta ja basson säestyksestä. Tietokoneohjelmat ovat puolestaan pääasiassa kehitetty analysoimaan ainoastaan yksiäänistä melodiaa. Sen vuoksi ensimmäisenä tehtävänäni oli tehdä analyyttinen äänitys, jotta pystyin erottamaan diskantin äänilähteenä bassosta. Äänityksen toteutetin siten, että asensin mikrofonin vuorotellen sekä harmonikan diskantti- ja bassokoteloon kiinni, jolloin tarpeettomat taajuusalueet leikkautuivat tehokkaasti pois. Äänityslaitteenani oli käytössä Sony Walkman Professional -nauhuri ja mikrofonina Sony-yhtiön valmistama stereomikrofoni. Äänityksen jälkeen "äänitin" analyysimateriaalin tietokoneen muistiin AD-muuntimen kautta, jolloin kasettinauhurin analoginen tieto muuttui tietokoneen vaatimaan digitaaliseen muotoon (Kuva 1). 


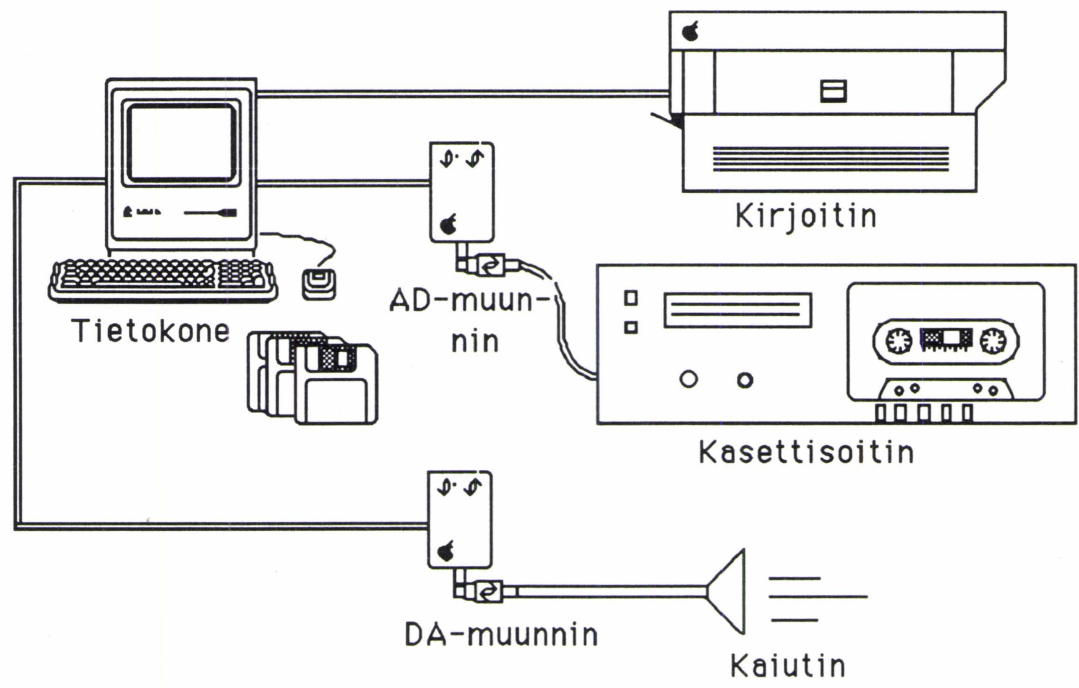

Kuva 1: Koko järjestelmän kuvaus

Signaalissa tapahtuvat intensiteetin muutokset tahdin mittaisessa osassa tietokone kuvasi kuvioina, joita tästä lähtien kutsun intensiteettikuvaajiksi (Esim. 1a ja 1b).

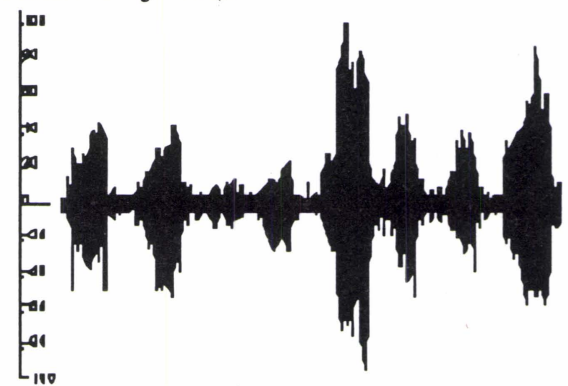

Esim. 1a MLK 1989, 1B5, tahti 2

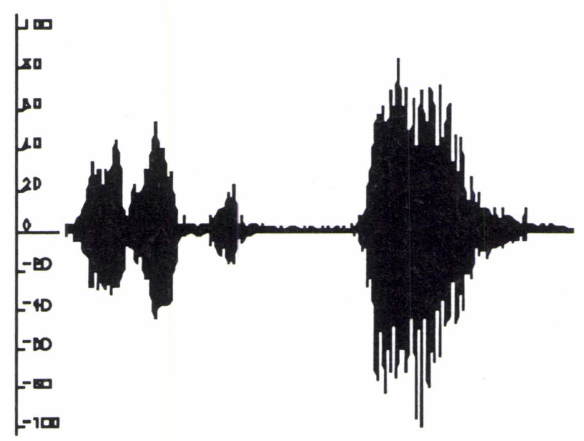

Esim. 1b MLK 1989, 1B5, tahti 8 
Kuviot esittävät siis signaalissa tapahtuvat intensiivisyyden muutokset suhteessa aikaan. Tietokone näyttää kuvaajassa kaiken, myös koneistoäänet (Esim. 1c).

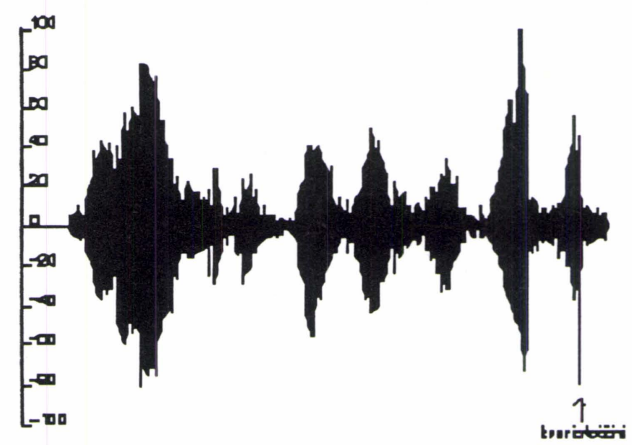

Esim. 1c MLK 1989, 1B5, tahti 7

Vaikka pystyin minimoimaan basson osuuden äänityksessä, aiheuttaa myös se pieniä poikkeamia kuvioissa (Esim. 1d).

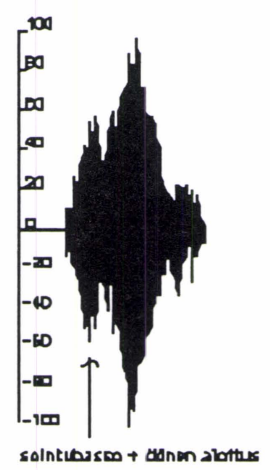

Esim. 1d. MLK 1989 1B5, tahdin 3 ensimmäinen neljäsosa

\section{Äänten voimakkuussuhteet tahdin mittaisessa osassa}

Analysoitavaksi kappaleeksi valitsin Tauno Ahon 11.11.1989 soittaman Kuortanelaisen polkan (1989, 1 B 5) 32 ensimmäistä tahtia. 


\section{Polkka}

MLK 1989, 1 B5
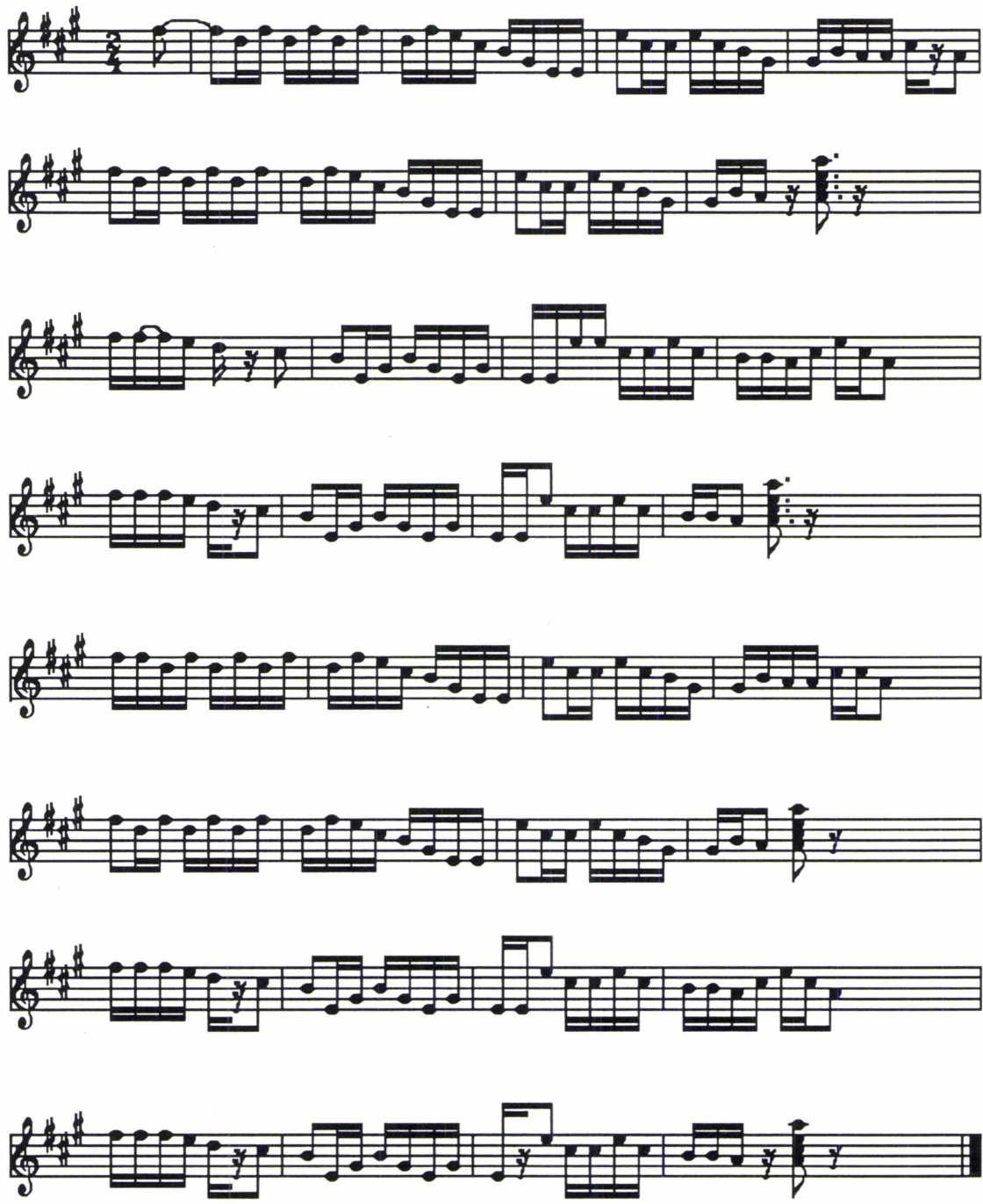

Esim. 2: Polkka

Analyysin ensimmäisenä työvaiheena oli materiaalin normalisointi tahdeittain (liite1), jolloin tahdissa oleva voimakkain ääni sai arvon 100 ja muut äänet taas vastaavasti suhteessa voimakkaimpaan lukuarvot väliltä 0 99.99. Huomattavaa katsottaessa tahdeittain normalisoituja intensiteettikuvaajia on se, että kaikissa voimakkaimmissa sävelissä ei aina suinkaan ole kysymyksessä ns. aksentti (palkeella nopealla nykäisyllä tuotettu voimakas 
ääni) vaan ainoastaan joka tahdissa oleva voimakkain ääni. Kaikki äänet ovat myös vertailukelpoisia toisiinsa nähden vain tahdin mittaisessa osassa, eivätkä esimerkiksi kahdeksan tahdin mittaisessa kokonaisuudessa.

Normalisoinnin jälkeen valitsin jokaisesta tahdista voimakkaimman ja toiseksi voimakkaimman äänen numeroarvojen 0-100 mukaan (Esim 3).

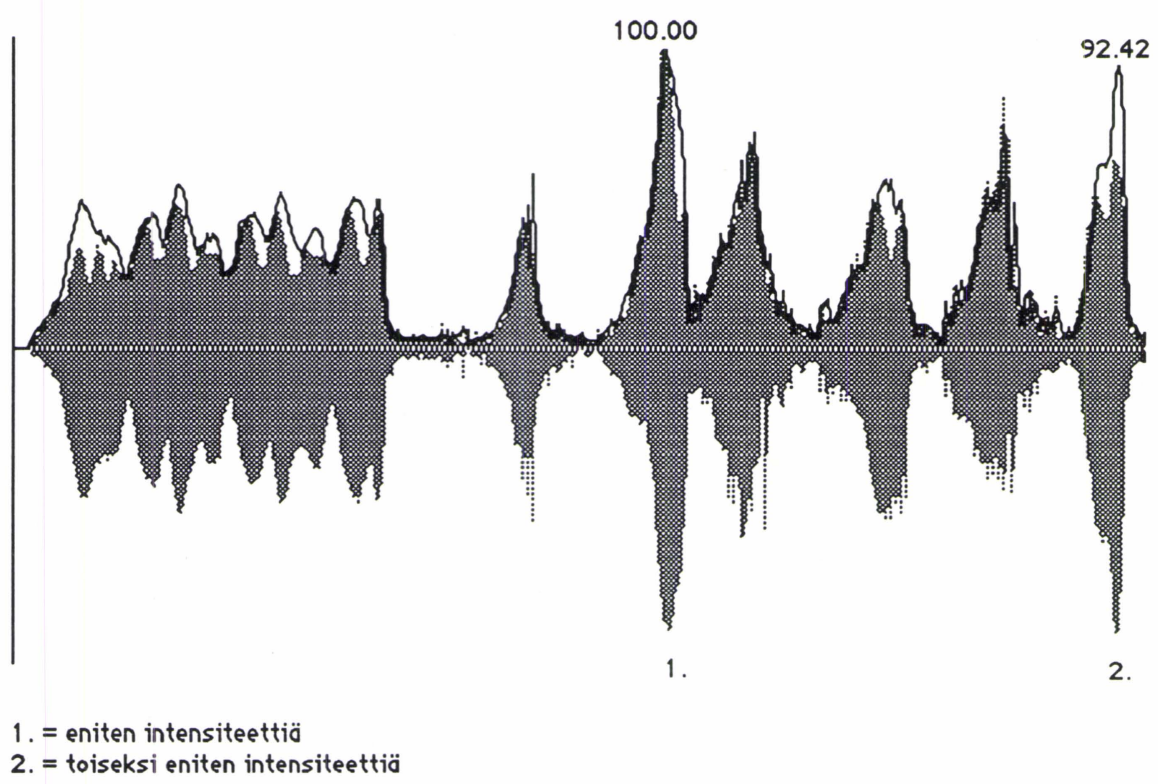

Esim. 3. MLK 1B5, tahti 1

Tämän jälkeen merkitsin muistiin, olivatko nämä kaksi voimakkainta säveltä tahdinosan painottomalla vai painollisella osalla. Tahdin painolliset ja painottomat osat jaoin jakamalla tahdin kuudestoistaosanuotteihin siten, että painollisia tahdinosia ovat ensimmäinen, kolmas, viides ja seitsemäs kuudestoistaosanuotti ja painottomia puolestaan toinen, neljäs, kuudes ja kahdeksas kuudestoistaosanuotti:

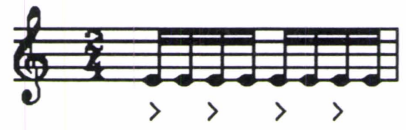

Tahdin mittaisessa osassa olevat rytmit tulkitsin selvyyden vuoksi siten, että jos esimerkiksi rytmissä 


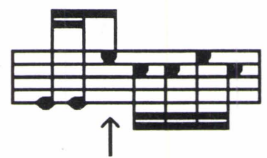

oleva kahdeksasosanuotti oli tahdin painokkain sävel, niin jaoin sen kahteen kuudestoistaosanuottiin ja niistä ensimmäinen sai voimakkaimman arvon ja toisen jätin huomioimatta:

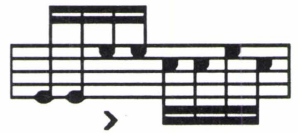

Analysoituani polkan kahden voimakkaimman sävelen osalta tahdeittain, iskullisella tahdinosalla voimakkaimpia oli $37 \mathrm{kpl}(58 \%)$ ja iskuttomalla $27 \mathrm{kpl}(42 \%)$. Melodian painolliset ja painottomat äänet ovat siis keskenään lähes yhtä tärkeitä ja tahdin voimakkaimmat äänet melodiassa voivat olla joko iskullisella, tai iskuttomalla tahdinosalla.

\section{Äänten pituussuhteet tahdin mittaisessa osassa}

Äänten pituussuhteet voimakkuussuhteiden kanssa muodostavat äänen kokonaisuuden, jonka ihminen suurina muutoksina aistii helposti. Pieniä muutoksia joko pituuksissa tai voimakkuuksissa on sen sijaan hyvin vaikea huomata. Tässä luvussa käsittelen äänten pituuksia tahdin mittaisessa osassa vertaillen eri aika-arvoja keskenään. Analysoitavana kappaleena on edelleen Tauno Ahon soittama polkka (1989, 1B5).

Aikaisemmin käsittelin Sound Designer -ohjelmasta saatavia intensiteettikuvaajia äänten voimakkuuksien tarkastelussa. Voimakkuuksien lisäksi kuvaajista näkee myös kunkin äänen pituuden (Esim. 4).

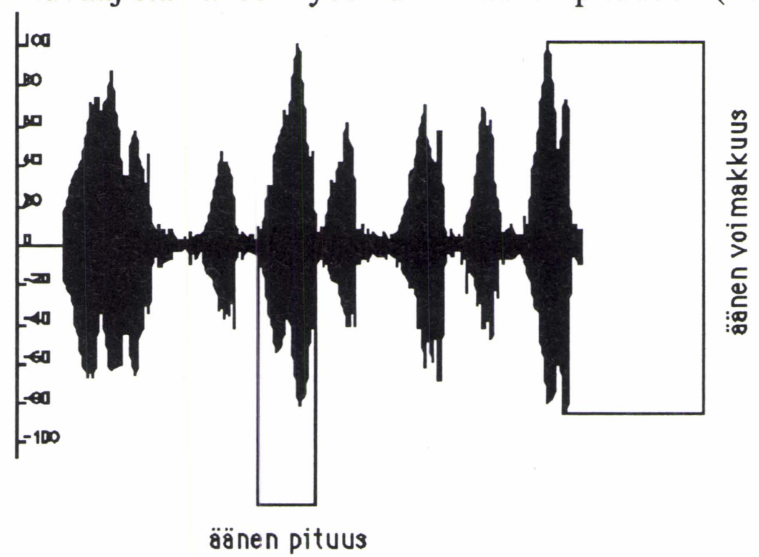

Esim. 4. MLK 1B5, tahti 21 
Analyysin aloitin järjestämällä identtisten segmenttien intensiteettikuvaajat alekkain. Tällöin aika-arvojen kestoja oli helppo verrata toisiinsa. Muunnellut tahdit jätin pois, koska ne erilaisuutensa vuoksi eivät olisi olleet analyysikelpoisia tähän osaan.

Analyysissä ovat mukana tahdit 1, 5, 21 (segmentti a), tahdit 2, 6, 18, 22 (segmentti b) ja tahdit 3, 7, 19, 23 (segmentti c), tahdit 9, 13, 25, 29 (segmentti f), tahdit 10, 14, 26, 30 (segmentti g) ja tahdit 15 ja 27 (segmentti h) (Esim. 5).

Segmentti a (tahdit 1,5 ja 21) intensiteettikuvaajat:

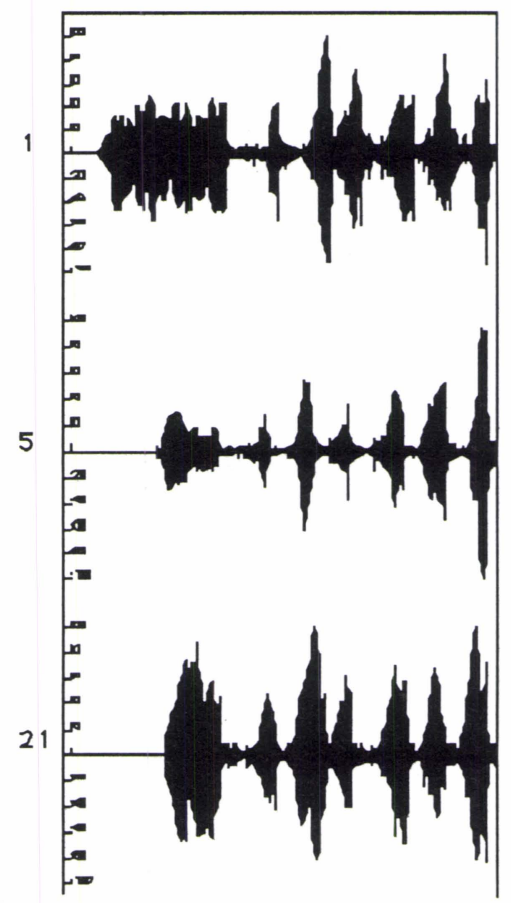

Nuotinnus:

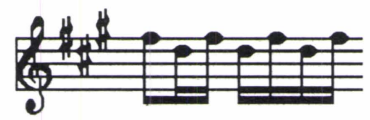

Tahdissa 1 kahdeksasosanuotti $\mathrm{f}^{\#}$ on pitempi kuin muissa tahdeissa. Tämä johtuu etuotosta, jonka Tauno Aho ottaa aloittaessaan kappaleen. Kahdeksasosanuotit tahdeissa 5 ja 21 ovat yhtä pitkiä. Tahdissa 1 ja 5 kuudestoistaosanuotit ovat keskenään yhtä pitkiä, mutta tahdissa 21 kuudestoistaosanuoteissa ovat kaikki f\#-sävelet hiukan pidempiä kuin d -sävelet. 
Segmentti b:n (tahdit 2, 6, 18 ja 22) intensiteettikuvaajat:

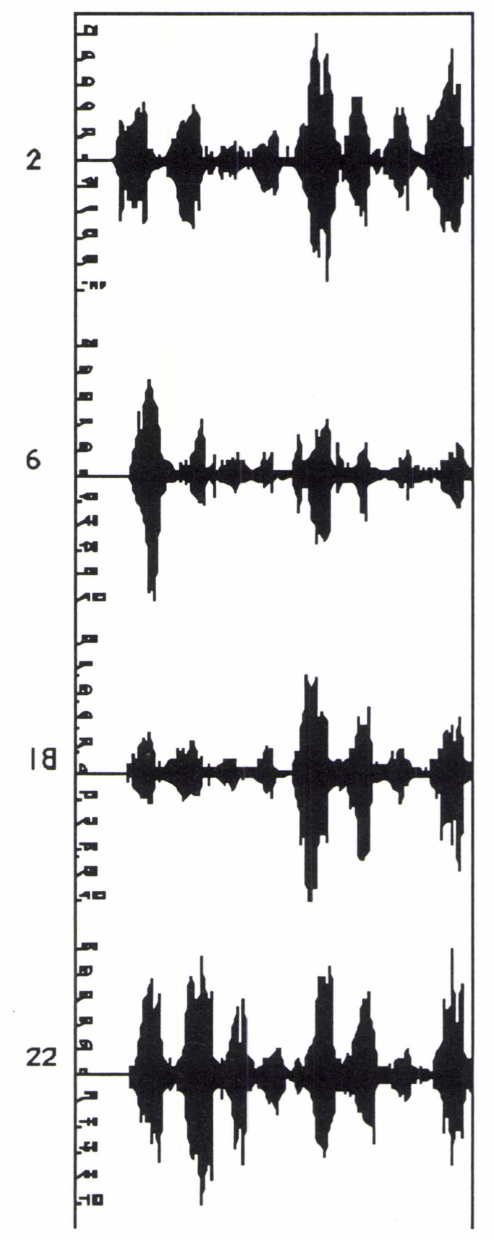

Nuotinnus:

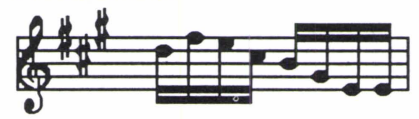

Kaikki kuudestoistaosanuotit ovat pituudeltaan yhtä pitkiä ja ainoastaan voimakkuudet eroavat toisistaan huomattavasti. Tahdin kolmas sävel $\mathrm{e}^{2}$ epäonnistuu sekä tahdissa 2 että tahdissa 6 , eikä näin ollen näy kuviossa kovin selvästi. 
Segmentti c:n (tahdit 3, 7, 19 ja 23) intensiteettikuvaajat:

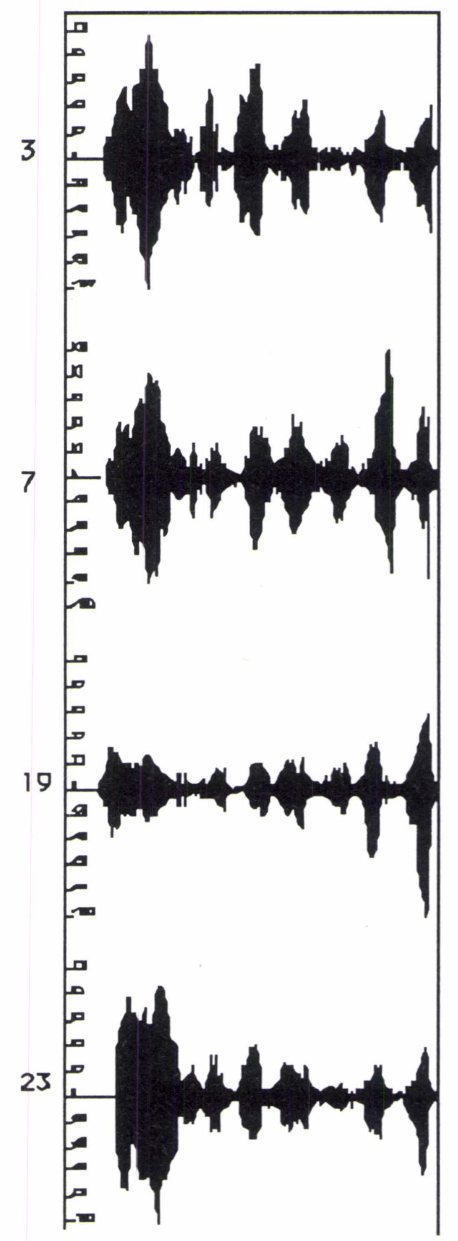

Nuotinnus:

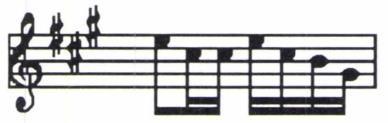

Segmentissä c oleva kahdeksasosanuotti on jokaisessa tahdissa yhtä pitkä samoin myös kuudestoistaosanuotit ovat yhtä pitkiä toisiinsa verrattuna. Tahdissa kolme oleva viides sävel $\mathrm{c}^{\# 2}$ on epäonnistunut eikä näy kuviossa. 
Segmentti f:n (tahdit 9, 13, 25 ja 29) intensiteettikuvaajat:

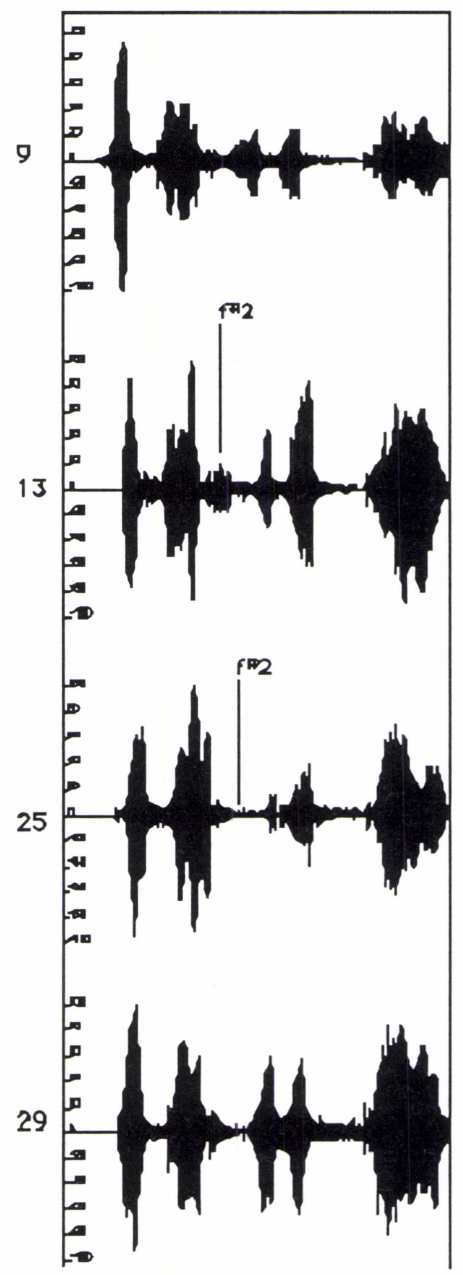

Nuotinnus:

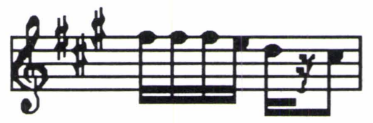

Segmentissä f olevat kuudestoistaosanuotit ovat kaikki yhtä pitkiä silloin kun ne onnistuvat. Tahdissa yhdeksän Tauno Aho yrittää ottaa kahta f\#2 säveltä peräkkäin mutta epäonnistuu. Tahdeissa 13 ja 25 niin ikään epäonnistuu tahdin kolmannen sävelen $\mathrm{f} 2$ otto, joten ne eivät näy kuvioissa. Viimeisenä oleva kahdeksasosanuotti $\mathrm{c}^{\# 2}$ on joka tahdissa yhtä pitkä. 
Segmentti g:n (tahdit 10, 14, 26 ja 30) intensiteettikuvaajat:

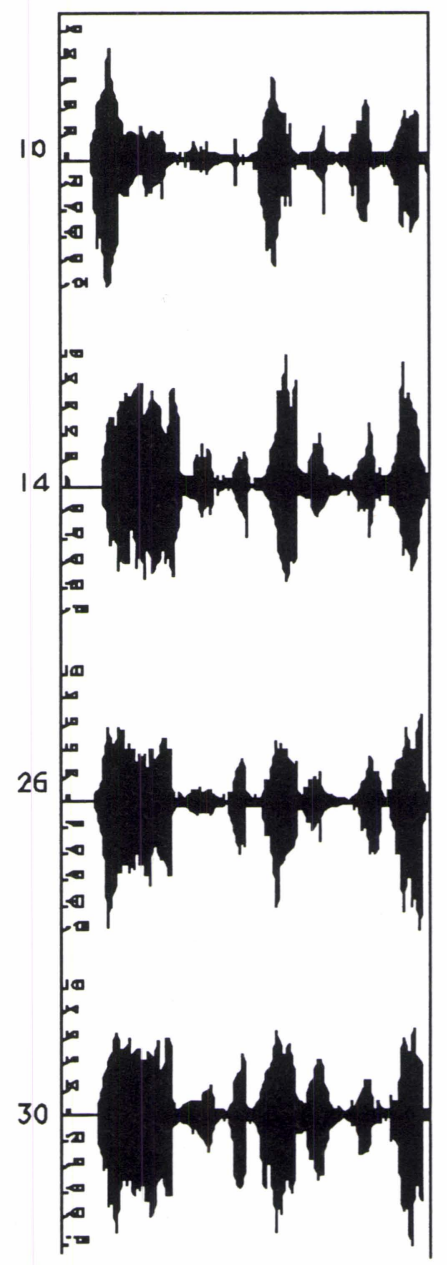

Nuotinnus:

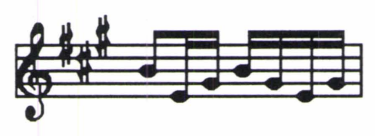

Tahdeissa olevat kahdeksasosanuotit ovat täsmälleen samanpituisia. Ensimmäisen neljäsosan kaksi viimeistä kuudestoistaosanuottia ovat hyvin teräviä. Terävämpiä kuin toisen neljäsosan neljä kuudestoistaosanuottia. Niistä ensimmäinen ja viimeinen ovat ehkä hiukan pidempiä kuin kaksi keskimmäistä. 
Segmentti h:n (tahdit 15, 27) intensiteettikuvaajat:

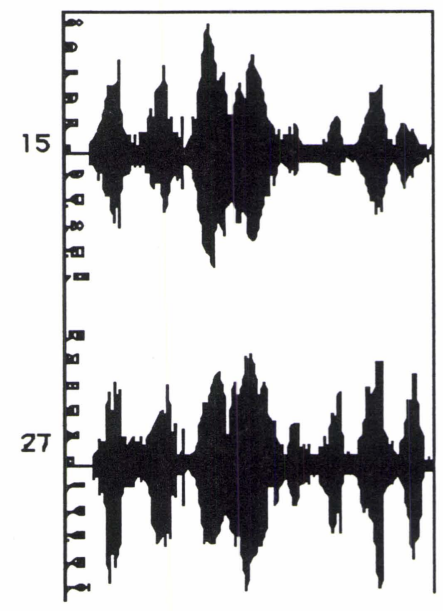

Nuotinnus:

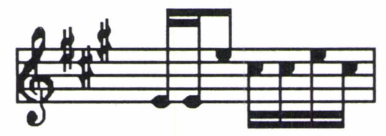

Tahdeissa olevat kuudestoistaosanuotit ovat keskenään samanpituisia samoin kuin kahdeksasosanuotit. Kahdeksasosanuotin kuvio on hiukan epäselvä sointubasson läpikuulumisen vuoksi. Varsinainen ääni on kuvion jälkimmäinen huippu.

\section{Intensiteetin kuvaus nuottikirjoituksessa}

Jotta edellä kuvatuista analyyseistä olisi myös hyötyä käytännön tasolla olisi sekä intensiteetti voimakkuuteena ja suhteessa aikaan pystyttävä siirtämään länsimaiselle notaatiojärjestelmälle. Perinteisesti länsimaisessa nuottikirjoituksessa pitkälliset intensiteetin muutokset ilmaistaan erilaisilla voimakkuusmerkinnöillä kuten esimerkiksi $p p p, p p, p, m p, m f, f, f f$, fff. Äkillisiä intensiteetin muutoksia taas merkitään esimerkiksi voimakkuusmerkinnöillä $s f, s f z$ ja symbolilla $>$. Tauno Ahon soitossa pitkällisiä intensiteetin muutoksia osoittavia voimakkuusmerkintöjä ei voida kuitenkaan käyttää, koska tällaisia muutoksia ei tapahdu. Äkillistä intensiteetin voimistumista osoittavissa voimakkuusmerkinnöissä ja symboleissa on se huono puoli, että ne eivät osoita, kuinka paljon intensiteetin pitäisi muuttua verrattuna yleiseen intensiteetin tasoon.

Tässä luvussa palataan jälleen kerran kappaleeseen MLK 1989 1B5, 
jota on tarkoituksenani seuraavaksi tarkastella sekä intensiteettikuvaajan että notaation avulla. Tarkoituksenani on kuvata erilaisia intensiivisyyden muutoksia nuottikuvassa. Tässä tapauksessa olen normalisoinut tietokoneen siten, että kahdeksan tahdin mittaisessa osassa ainoastaan yksi ääni eli voimakkain saa voimakkaimman arvon eli 100 ja kaikki muut vastaavasti pienemmän arvon. Sen jälkeen olen jokaisesta neljän tahdin mittaisesta osasta numeroinut neljä voimakkaimman arvon saanutta ääntä. Voidakseni merkitä eri intensiivisyyden muutokset nuottikuvalle, olen päätynyt seuraaviin symboleihin:

\begin{tabular}{|l|l|c|} 
intensiteetti & kuvaus & merkintä \\
\hline $100-80$ & voimakas korostus & $>$ \\
$80-60$ & melko voimakas korostus & $>$ \\
$60-40$ & pieni korostus & $>$ \\
\hline
\end{tabular}

Taulukko 1. Intensiteetin kuvaus nuottikirjoituksessa

Intensiteettikuvaajan ja notaation avulla lopputulos on seuraavanlainen; vaikka äänten pituuksilla oli jonkin verran eroja, olivat erot mielestäni niin pieniä ja sattumanvaraisia, ettei niitä ollut tarpeellista sisällyttää nuottikuvaan: 
Tahdit 1-8
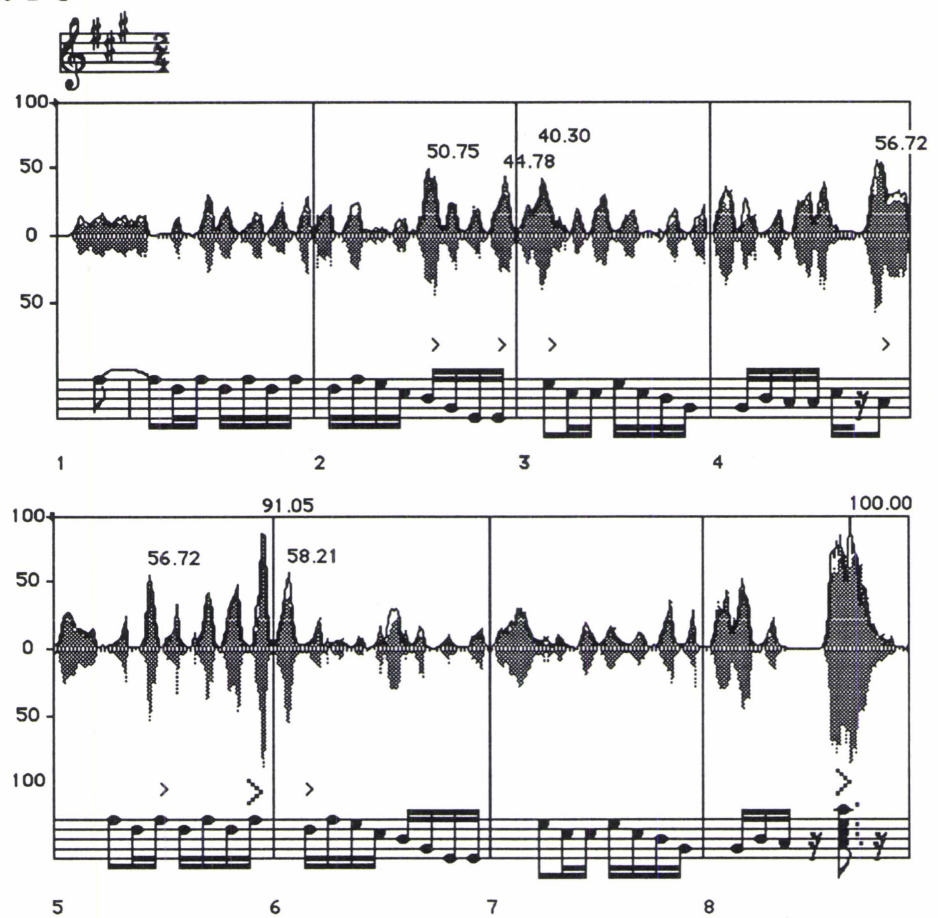

Tahdit 9-16
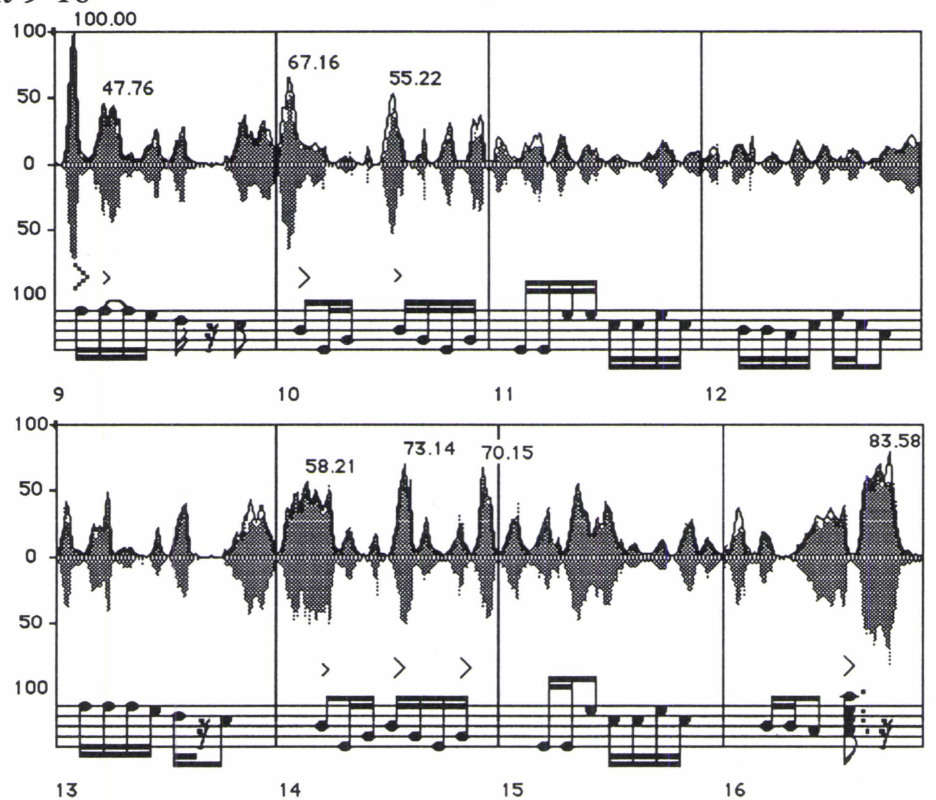
Tahdit 17-24

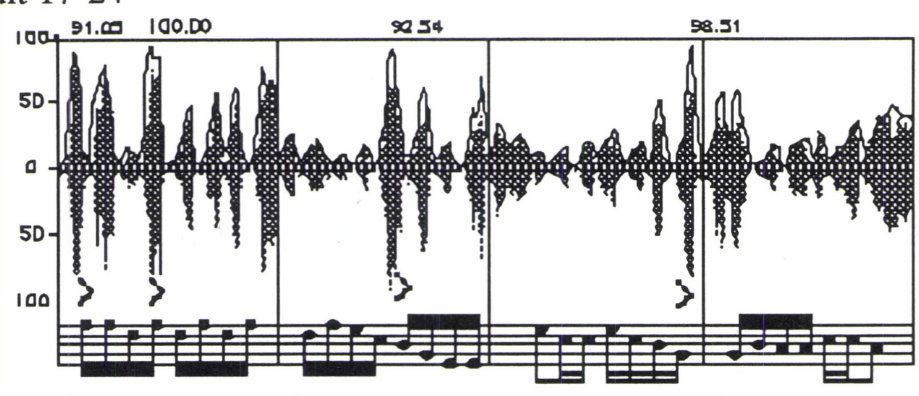

17

1B

19

2D

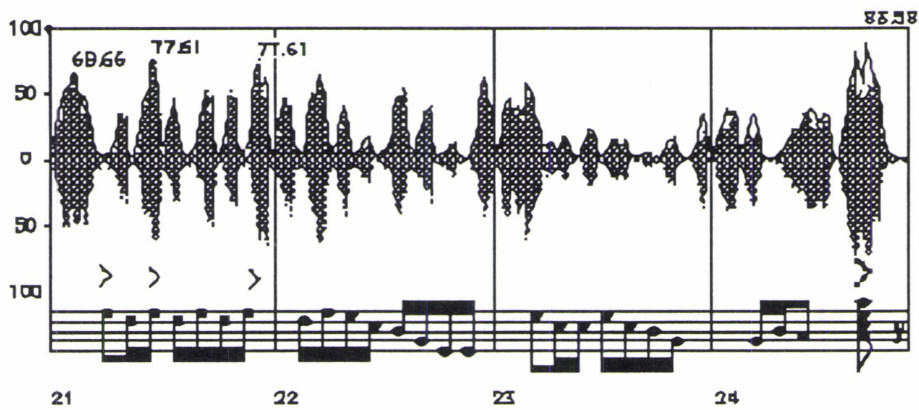

Tahdit 25-32
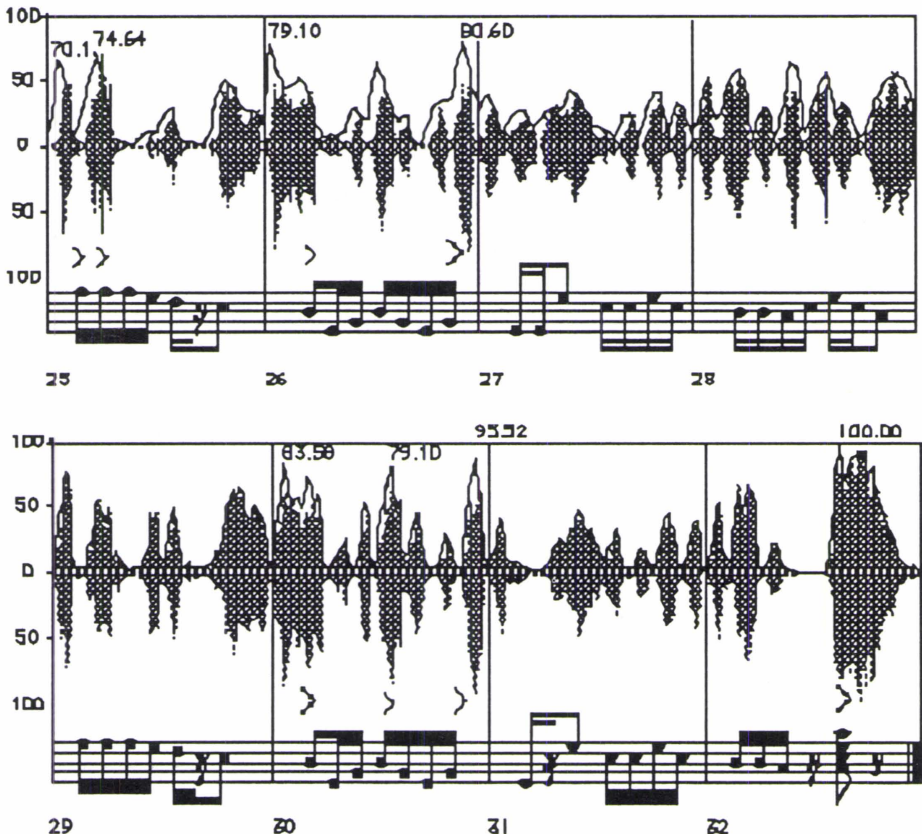


\section{Tulokset ja niiden tarkastelu}

Tässä analyysissä en kiinnittänyt huomiota kuin kahteen asiaan, äänen voimakkuuteen verrattuna toisiin ääniin ja äänen pituuteen verrattuna toisiin ääniin. Voimakkain ääni tahdissa saattoi olla joko tahdin iskullisella tai iskuttomalla osalla, eikä vain iskullisella, kuten voisi olettaa. Äänten pituuksilla ei Tauno Ahon soitossa ollut sanottavasti eroja. Kuudestoistaosanuotit ja kahdeksasosanuotit olivat hämmästyttävän samanpituisia. Todennäköisesti Tauno Aho pyrkiikin soittamaan polkat mahdollisimman tasaisesti staccatossa. Ns. synkooppijuoksutusta ei Tauno Ahon soitosta löytynyt äänten pituuksilla. Sen sijaan äänten voimakkuuksilla tuntuu olevan hyvin paljon tekemistä synkooppijuoksutuksen ja yleensäkin svengaavan soittotyylin kanssa. Periaatteessa tällaisen efektin voi toteuttaa joko äänten pituuksilla tai äänten voimakkuuksilla. Kuulovaikutelma on kummassakin tapauksessa hyvin lähellä toisiaan.

Tässä analyysitavassa on paljon puutteita ja se antaa hyvin kärjistetyn vastauksen esimerkiksi äänten voimakkuussuhteista, jako kolmeen eri korostustasoon on vain yksi esimerkki. Anaiyysi ei myöskään ota huomioon sitä, kuinka paljon kyseiset tulokset johtuvat yksinomaan soittimen kunnosta. Myös hyviä puolia löytyy ja varmasti suurin kehitys tapahtuu oman kuuloaistin kohdalla.

Mikäli Tauno Ahon kappaleita ja yleensä muutakin kansanmusiikkia halutaan esittää nuotteina, olisi syytä kiinnittää paljon enemmän huomiota muuhunkin kuin säveltasoihin. On pystyttävä kuvaamaan musiikkia sen omilla ehdoilla. Jos siihen ei länsimainen notaatiosysteemi yksistään riitä, olisi keksittävä joko kokonaan uusia tai rinnakkaisia vaihtoehtoja.

\section{Lähteet}

Ahlbäck, Sven

1986 "Karaktäristiska egenskaper för låttyper i svensk folkmusiktradition - ett försök till beskrivning." Solna.

Kolehmainen, Ilkka

1989 "Hanuri suomalaisessa kansanmusiikissa." Kansanmusiikki 3. Kauhava.

Pekkilä, Erkki

1981 "Salomon Katilan juoksuvalssit: Kulttuurinen musiikkiana-

Pekkilä, Erkki lyysi." Musiikki 2.

1988 "Musiikki tekstinä. Kuulonvaraisen musiikkikulttuurin analyysiteoria ja -metodi." Suomen Musiikkitieteellinen Seura, Acta Musicologica Fennica 17. Jyväskylä. 
LIITE 1: Intensiteettikuvaajat tahti kerrallaan normalisoituna
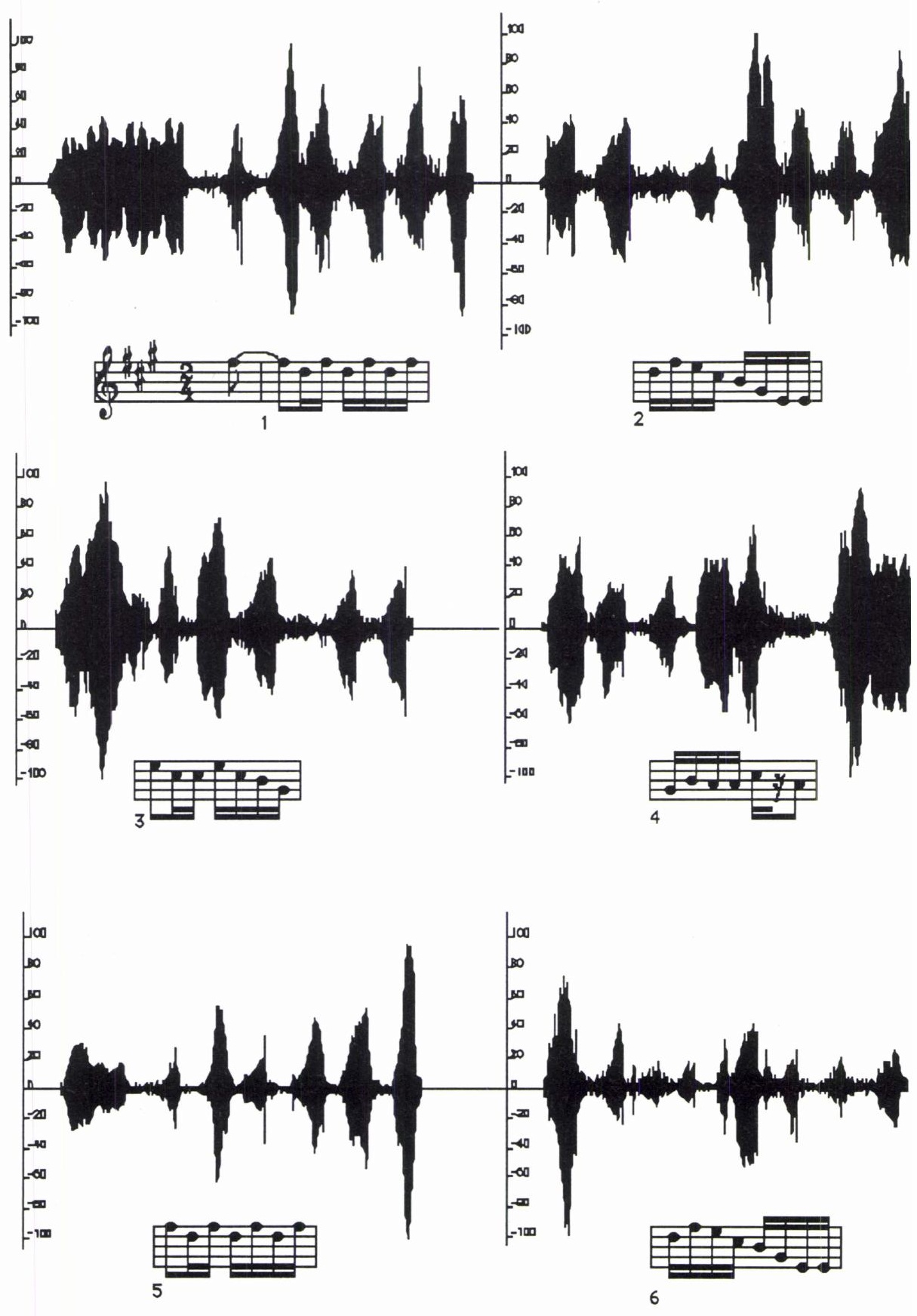


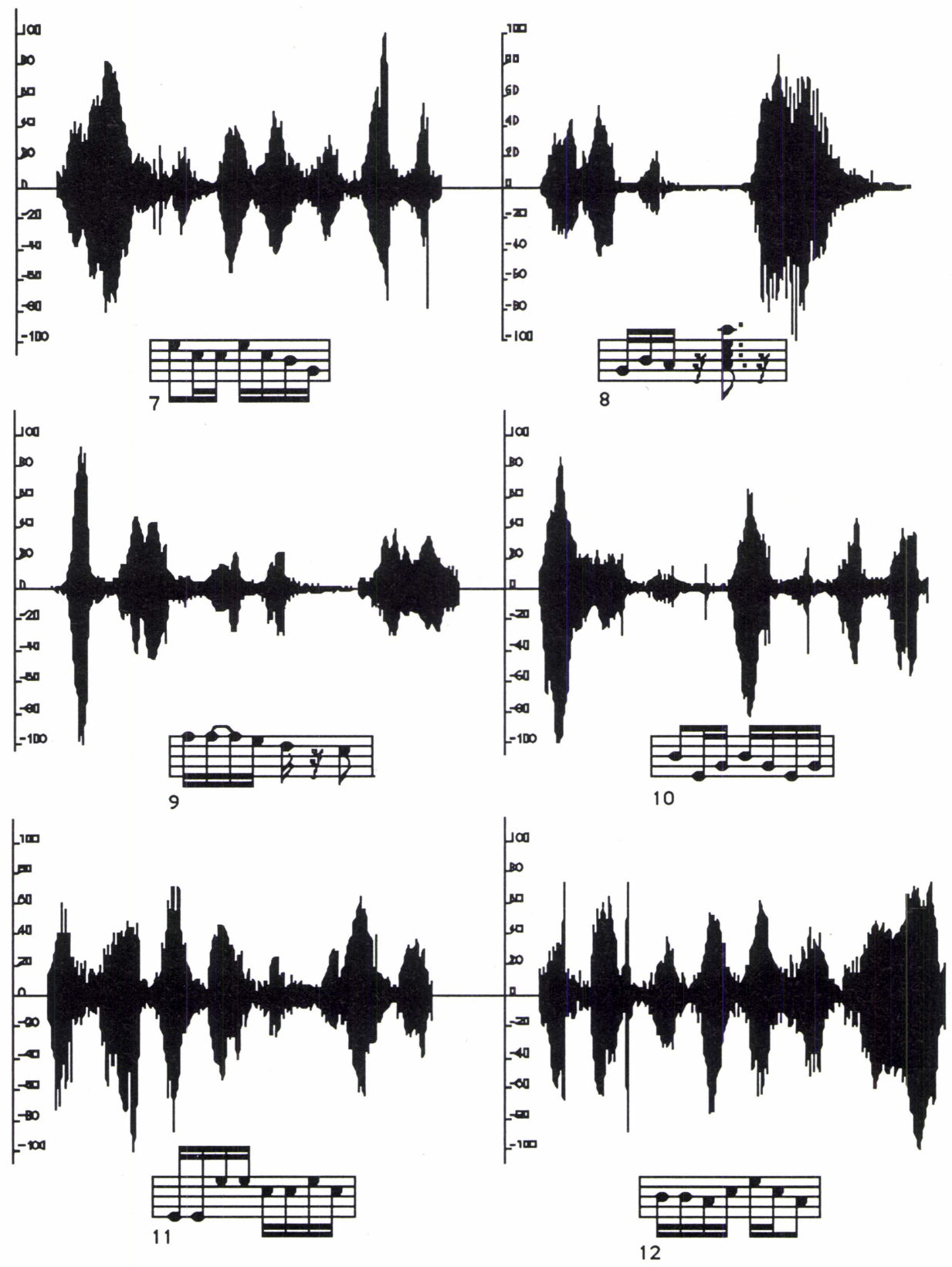



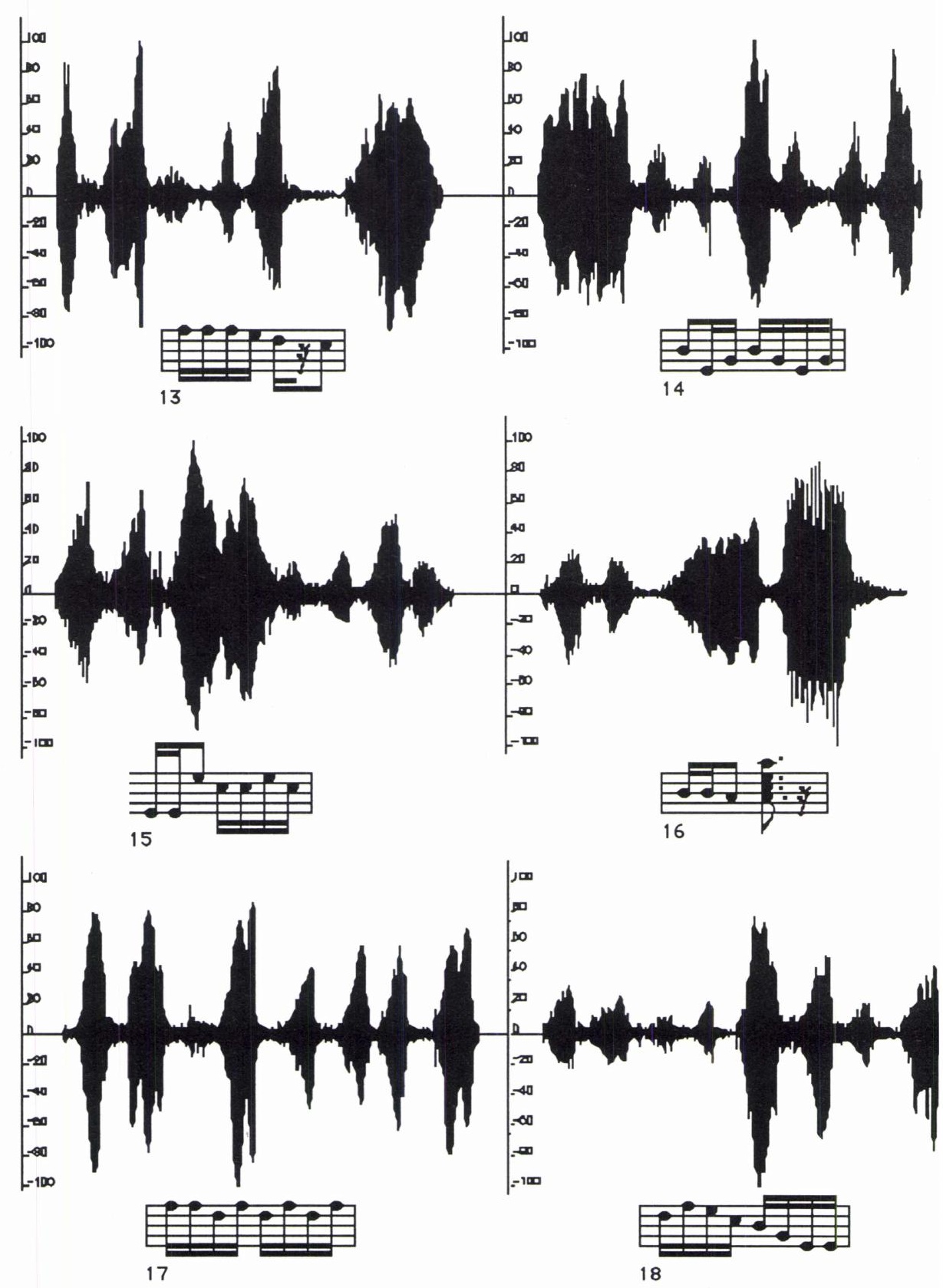

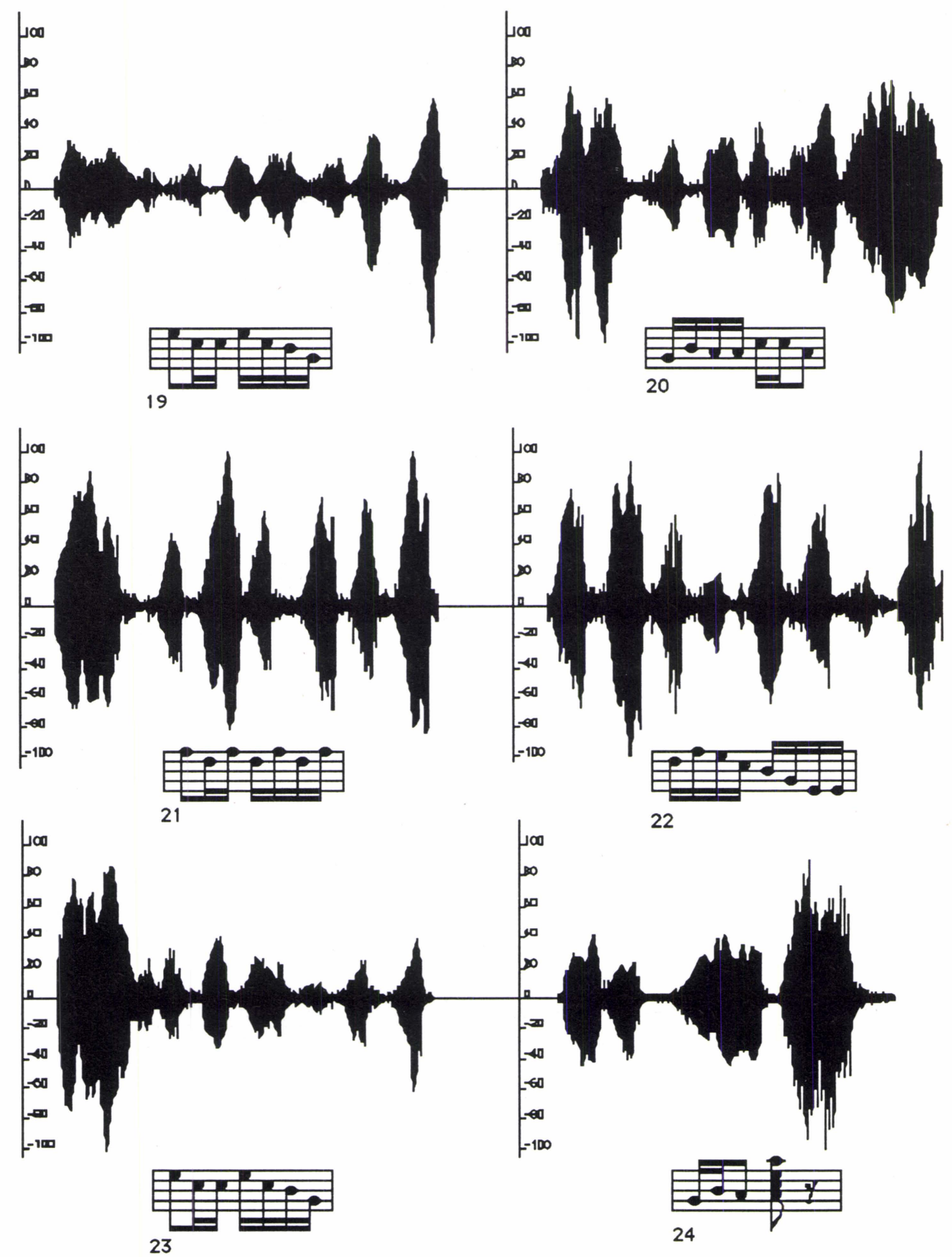
Markku Lepistö
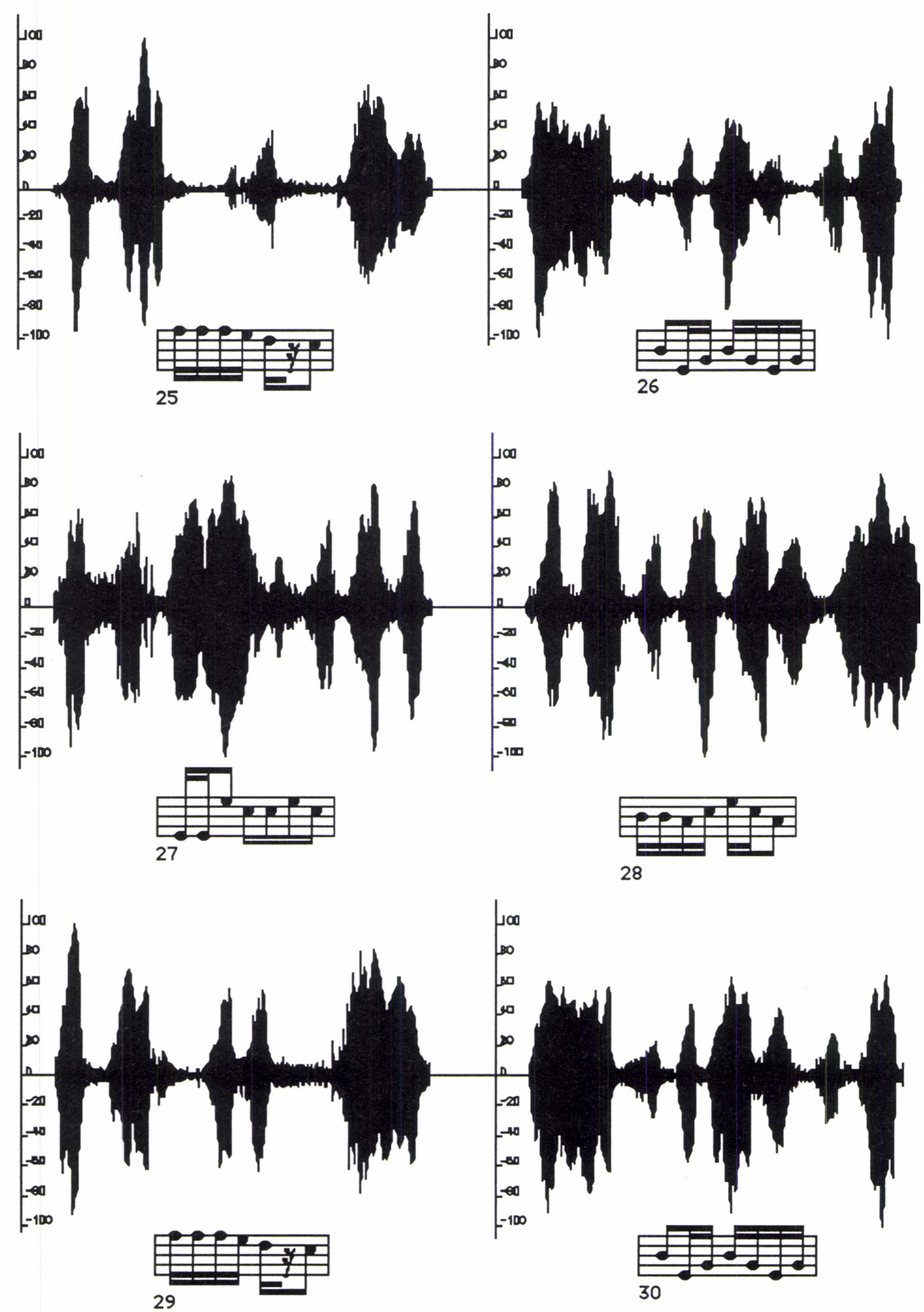


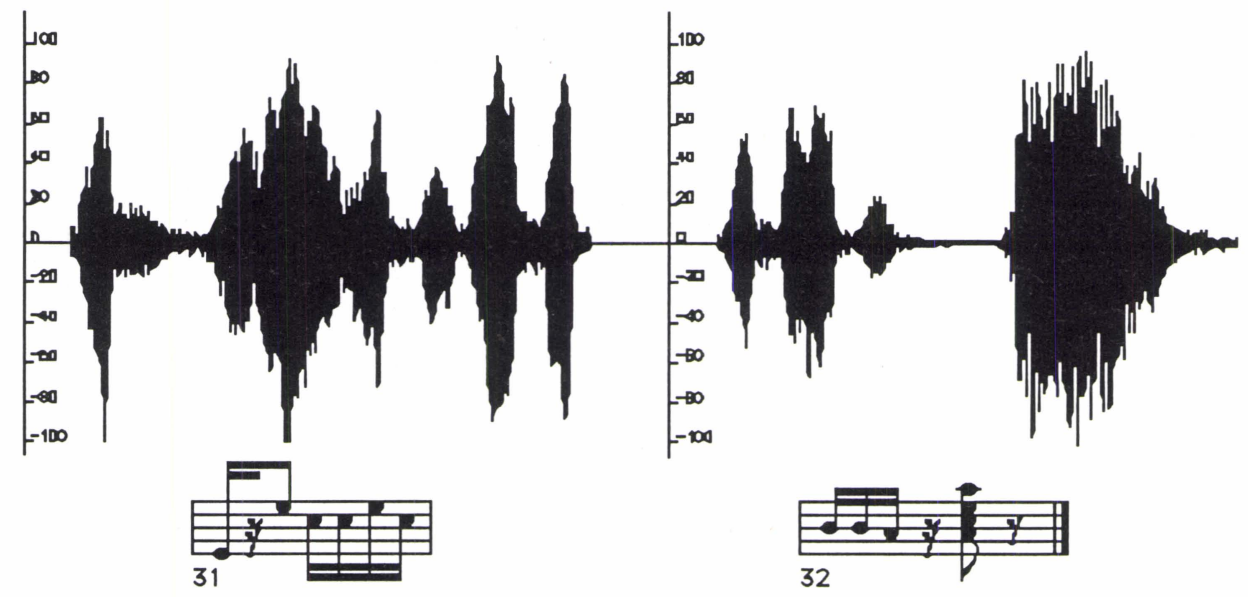

